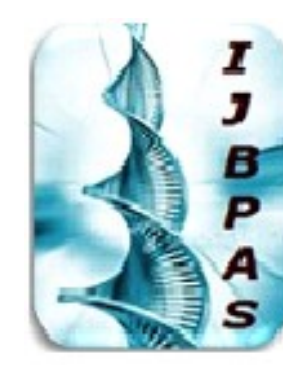

International Journal of Biology, Pharmaey and Allied Sciences (IJBPAS)

'A Bridge Betuen caboratory and QRender'

WwW.ibpas.com

\title{
A STUDY OF INDIAN SNACKS MARKET IN MAHARASHTRA
}

\section{JAYDEEP TANKSALE}

Symbiosis Institute of Business Management Pune, Symbiosis International (Deemed

University), Pune, India

*Corresponding Author: E Mail: jaydeep.tanksale.mbals22@associates.sibmpune.edu.in

Received $19^{\text {th }}$ May 2021; Revised $4^{\text {th }}$ June 2021; Accepted $9^{\text {th }}$ July 2021; Available online $25^{\text {th }}$ Sept. 2021

https://doi.org/10.31032/IJBPAS/2021/10.9.1004

\begin{abstract}
The present study was conducted in three districts of Maharashtra with the help of personal interview of 150 retailers to understand the status of distribution, factors affecting distribution and the satisfaction level of retailers with sales services. It was found that availability at retail outlet is the major factor influencing purchase of packaged snack food products followed by taste, quantity, quality and freshness of the products. Instant gratification is the main purpose behind purchasing of packaged snack food products. Packaged snack food product brands should launch new products to satisfy the variety seeking baying behaviour of consumers. They should also take extra care for proper arrangement and visibility backed by proper availability of the products at retail outlets.
\end{abstract}

Keywords: Snack food, Distribution, Availability, Factors affecting, Retailers satisfaction \section{INTRODUCTION}

The snack food industry is constantly growing and evolving. The growth of modern trade has helped stimulate a revolution in the packaged food industry in India. Packaged snack food products are FMCG products and distribution is a quite important factor. Proper distribution of all range of products, availability at retail outlet and sales services helps to increase

market share of FMCG products. Distribution of packaged snack food products to maintain proper availability at retail outlets is a challenging task for markets due to increasing competition and availability of number of brands in packaged snack food products (Anonymous 2009). Majority consumers make a purchase of packaged snack food products 
for instant gratification. Unavailability of one brand may switch off the consumer towards another available brand. The study involves 3 districts of Maharashtra. For better understand the situation of rural retailers the study involves retail outlets in the ratio of $4: 1$ from urban and rural areas, respectively. Hence the present investigation was undertaken to know the status of distribution of different packaged snack products in Maharashtra.

\section{MATERIALS AND METHODS}

The study was carried out in 3 districts Nanded, Beed and Hingoli of Maharashtra. Total 6 talukas, 2 each from one district were selected. One of these talukas was predominantly urban and other rural. Survey was carried out during the year 2020. The study involved 150 retailers in 3 districts of Maharashtra. Personal interviews method was used for collection of primary data. The research instrument used for data collection was structured and non-disguised questionnaire. Data was analyzed quantitatively using simple statistical analysis tools such as averages and percentages. Besides it ranking and scaling techniques were employed. Retailers were selected using purposive sampling method on the basis of availability of products at their retail outlet in the respective market in the ratio of $4: 1$ from urban and rural areas respectively. In this survey all type of retail outlet were involved like departmental stores, restaurants, tourist place, bakeries, small retailers, kiosks, rural retailers and retailers on highway. Rural retailers were involved to know the satisfaction level of retailers with salesservices.

\section{RESULTS AND DISCUSSION}

\section{Education and monthly turnover of retailers}

Packaged snack food products are available at almost all type of retail outlet. Data was collected from 3 districts of Maharashtra Nanded, Hingoli and Beed covering 6 Talukas of these districts and all type of retail outlets were involved in this study. Information was collected from total 150 retailers. Out of those 150 retailers, qualification of 32.66 percent retailers was below S.S.C., 27.33 percent were educated up to S.S.C., 24percent retailers were up to H.S.C. and 16 percent retailers were graduate. Among those retailers 24percent retailers had monthly turnover above 1,00,000 Rs. While 7.33 percent retailers turnover was less than 20,000. It shows that branded snack products are available at each and every type of retailoutlet (Table 1).

\section{Type of packaged snack food products}

\section{stocked by retailers}

From those 150 retailers, all retailers stocked ready to cook/eat products at their retail outlet. 96.66 percent retailers stocked 
beverages, 95.33 percent retailer stocked biscuits and bakery products, 98 percent stocked confectioneries, 70 percent stocked processed foods and 50.66 percent retailer stocked traditional foods while only 27.33 percent retailer stocked staples at their retail outlet (Table 2).

Information was collected from rural as well as urban retailers who stocked packaged snack food products at their retail outlet. In both the areas availability of regional brands is highest followed by unbranded products, national brands and local brands. It was found that penetration of national brands is more in urban areas as compared to rural areas.86.66 percent retailer stocked unbranded packaged snack or non packaged items. 70.66 percent retailer stocked National brands like Lays, Haldiram, Parle, and ITC etc while 47.33 percent retailer stocked local brands like Bhargav, Pinkoo at their retail outlet. All the retailers stocked regional brands such as Balaji, Everest and Samrat (Figure 1, 2).

When availability of different SKU's was checked, Lays has highest availability at retail outlet. At 23 percent retail outlet Lays had more than 15 SKU's followed by Balaji (12\%). At 51 percent retail out let 11-15 SKU's of Lays was there, followed by Balaji (40\%), ITC (13\%), Haldiram $(10 \%)$ and Everest (8\%). 48 percent of retailers keep 6-10 SKU's of Balaji. Lays had provide the highest no. of SKU's (47) followed by Everest (32), Balaji (25), Haldiram (13) and ITC (11). Lays provide 100 percent replacement on expiry products while Balaji do not provide replacement on expiry products, so only fast moving products are kept by retailers. It shows that replacement policy of company help to increase availability and visibility of slow moving products which will increase impulse purchasing of those products. When it was asked why packaged snack food products are preferred than 83 percent retailers told that they prefer because packaged snack food products are demanded by customers while 17 percent retailers informed that sales of packaged snack food products directly affect total sales of their retail outlet. The small scale retailer agreed that sale of packaged snack food products helps to increase their totalsales/turnover (Table 3, Figure 3, 4).

\section{No. of cartons kept as a stock}

Sales persons regularly visit retail outlet so retailers do not keep much stock of products. Products are also available as per requirement in cartons or in strip of 6 packages so retailers purchase as per the requirement of product. Big retailers purchased carton while small scale retailers purchase in strips as per their demand.

According to retailers, the major factors affecting purchase are availability, followed by taste, quantity and quality. In rural areas freshness and price is given 
more important. While in urban areas taste, quantity and quality were given more important. According to retailers' availability of particular brand at retail outlet was the major factor influencing purchase of packaged snack food products followed by taste, quantity, quality and freshness of packaged snack food products.

Type of packaged snack food products purchased by customers

According to majority (35.33\%) retailers wafers and crunchy salty snack products both products were purchased by most of the customers followed by 30 percent retailers told that wafers were purchased most by customer and 16 percent retailers told that all 3 range of productswafers, crunchy salty snack products and salty were equally purchased by customer at their retail outlet (Table 4).

Customers of packaged snack food products

Among the retailers 19 percent told that only children purchased packaged snack food products while according to majority $(81 \%)$ retailers everybody purchase and take packaged snack food products for instant gratification as well as to enjoy the great taste and different varieties of packaged snack food products.

Purpose behind purchase of packaged snack food products

According to $88 \%$ retailer instant gratification was the main purpose behind purchasing packaged snack food products followed by second major purpose of school breakfast. According to 71.33 percent retailers, consumers purchasing packaged snack food products for their children were purpose behind purchasing packaged snack food products followed by festival, picnic and parties (Table 5).

According to 77 percent retailers rupees five price point was most preferable while 21 percent retailers told that both the price points Rs. 5 and Rs. 10 is equally preferable, while only 2 percent retailers told that all price point of packaged snack food products were sold equally at their retail outlet.

Ranking of various packaged snack food brands

Retailers ranked various packaged snack food brands vis-a-vis its competitors on above parameters. From the studies it was concluded that in terms of brand name, range of products, quality and promotional activities, Lays was better than Balaji in the surveyed area (Table 6). In terms of margin, quantity, availability, distribution network, demand. According to 77 percent retailers rupees five price point was most preferable while 21 percent retailers told that both the price points Rs. 5 and Rs. 10 is equally preferable, while only 2 percent retailers told that all price point of packaged snack food products were sold equally at their retail outlet. 
Ranking of various packaged snack food brands

Retailers ranked various packaged snack food brands vis-a-vis its competitors on above parameters. From the studies it was concluded that in terms of brand name, range of products, quality and promotional activities, Lays was better than Balaji in the surveyed area (Table 6). In terms of margin, quantity, availability, distribution network, demand.

Share of packaged snack food products in total food products sold by retailers

In urban areas share of packaged snack food products in total sales ranges between food products sold by retailers is 10-20 percent, followed by 21-40 percent and 4160 percent. While in rural areas at small kiosk type of retail outlets share of packaged snack food products was 61-80 percent and even above 81 percent (Table 7).

Effect of visibility on the sales of packaged snack food products

Packaged snacks food products are generally purchased on impulse so visibility directly affects sales of these types of products. According to 68 percent retailers, visibility affects the sales of such packaged snack food products while 32 percent retailer told that packaged snack food products is demanded even without any visibility (Table 8).
Incentives provided by packaged snack food product brands

The study revealed that $10-15$ percent retailer margin is provided by various companies of packaged snack food products. Different type of POP material was also provided to the retailer for good visibility of their products at retail outlet. Discounts, free pack on bulk purchase was also given by National brands like Lays, ITC and Haldiram to the retailers. One of the popular regional brand Balaji was not providing any type of POP material or discount to the retailers (Table 9).

\section{Satisfaction level towards incentives}

Majority retailers $(72 \%)$ were satisfied with the incentives given by various brands while by 28 percent retailers were not satisfied with the incentives given to them. According to satisfied retailers certain companies provided less retail margin but they provided POP material and discounts while on other hand certain companies provide more retail margin and do not provide any other incentives.

Delivery of all price points according to requirement (Table 10, 11)

\section{Information about new product ranges}

Majority (91\%) retailers told that sales person inform them about new products introduced by the company. While others get themselves aware from market and ask for new products (Table 12). 
Satisfaction level of retailers with service level (Table 13)

Among them 86 percent retailers told that dealers/sales persons supply products according to their requirement while 14 percent retailers told that they don't get products according to their requirement.

Regular supply of packaged snack food products to retailers

Distribution network of various packaged snack food products brands works effectively in rural areas as well as urban areas. In rural areas 97 percent retailers told that products were delivered regularly while only 3 percent rural retailers told that they did not get regular supply of packaged snack food products. In urban areas 89.16 percent retailers get regular supply of packaged snack food products. While, 10.83 percent retailers did not get regular supply of packaged snack food products.

\section{Visit of sales persons rural and urban}

Sales persons of various packaged snack food products brands visited the retail outlets regularly in Maharashtra. According to majority (60\%) retailers of rural areas told that sales person visit twice in a week followed by 23 percent retailers told that sales person visit above 15 days, 13 percent retailers told that sales person visit once in a week while 4 percent retailers told that sales person do not visit their shop, they go to dealer's godown and purchase products. In urban areas majority $(95 \%)$ retailers told that sales person visit twice in a week followed by 3 percent retailers told that sales person visit once in a week while 2 percent retailers told that sales person do not visit their shop.

\section{Deliveries of all range of products}

According to majority (89.33\%) retailers all range of products were delivered by sales person. However 10.66 percent retailer mostly in rural areas complained about unavailability of complete range.

Among them 86 percent retailers told that dealers/sales persons supply products according to their requirement while 14 percent retailers told that they don't get products according to their requirement.

Regular supply of packaged snack food products to retailers

Distribution network of various packaged snack food products brands works effectively in rural areas as well as urban areas. In rural areas 97 percent retailers told that products were delivered regularly while only 3 percent rural retailers told that they did not get regular supply of packaged snack food products. In urban areas 89.16 percent retailers get regular supply of packaged snack food products. While, 10.83 percent retailers did not get regular supply of packaged snack food products.

Visit of sales persons rural and urban 
Sales persons of various packaged snack food products brands visited the retail outlets regularly in Maharashtra. According to majority $(60 \%)$ retailers of rural areas told that sales person visit twice in a week followed by 23 percent retailers told that sales person visit above 15 days, 13 percent retailers told that sales person visit once in a week while 4 percent retailers told that sales person do not visit their shop, they go to dealer's godown and purchase products. In urban areas majority
$(95 \%)$ retailers told that sales person visit twice in a week followed by 3 percent retailers told that sales person visit once in a week while 2 percent retailers told that sales person do not visit their shop.

\section{Deliveries of all range of products}

According to majority (89.33\%) retailers all range of products were delivered by sales person. However 10.66 percent retailer mostly in rural areas complained about unavailability of complete range.

Table 1 Education detail and monthly turnover of retailers

\begin{tabular}{|c|c|c|c|c|c|}
\hline Particulars & $\begin{array}{l}\text { No. of respondents } \\
\text { in Nanded }\end{array}$ & $\begin{array}{l}\text { No. of respondents } \\
\text { in Beed }\end{array}$ & $\begin{array}{l}\text { No. of } \\
\text { respondents in }\end{array}$ & $\begin{array}{l}\text { No. of total } \\
\text { respondents }\end{array}$ & Percentage \\
\hline & & Education & Hingoli & & \\
\hline Below S.S.C. & 18 & 12 & 19 & 49 & 32.66 \\
\hline S.S.C. & 15 & 13 & 13 & 41 & 27.33 \\
\hline H.S.C. & 10 & 15 & 11 & 36 & 24.00 \\
\hline Graduate & 07 & 10 & 07 & 24 & 16.00 \\
\hline \multirow[t]{2}{*}{ Total } & 50 & 50 & 50 & 150 & 100 \\
\hline & & Monthly turnover & & & \\
\hline Less than 20,000 & 10 & 05 & 06 & 11 & 7.33 \\
\hline $21,000-40,000$ & 07 & 08 & 05 & 20 & 13.33 \\
\hline $41,000-60,000$ & 08 & 06 & 09 & 23 & 15.33 \\
\hline $61,000-80,000$ & 10 & 04 & 10 & 24 & 16.00 \\
\hline $81,000-1,00,000$ & 09 & 09 & 08 & 26 & 17.33 \\
\hline Above $1,00,000$ & 06 & 18 & 12 & 36 & 24.00 \\
\hline Total & 50 & 50 & 50 & 150 & 100 \\
\hline
\end{tabular}

Table 2 Type of packaged snack food products stocked by retailers

\begin{tabular}{|c|c|c|c|c|c|}
\hline $\begin{array}{l}\text { Packaged snack food products } \\
\text { stocked by retailer }\end{array}$ & $\begin{array}{l}\text { No. of respondents } \\
\text { in Nanded }\end{array}$ & $\begin{array}{c}\text { No. of } \\
\text { respondents in }\end{array}$ & $\begin{array}{c}\text { No. of } \\
\text { respondents in }\end{array}$ & $\begin{array}{l}\text { No. of total } \\
\text { respondents }\end{array}$ & Percentage \\
\hline Ready to cook/eat & 50 & Bred & Hifấgoli & 150 & 100 \\
\hline Beverages & 47 & 48 & 50 & 145 & 96.66 \\
\hline Biscuits and bakery & 48 & 47 & 48 & 143 & 95.33 \\
\hline Confectioneries & 50 & 49 & 48 & 147 & 98.00 \\
\hline Processed foods & 39 & 35 & 31 & 105 & 70.00 \\
\hline Traditional foods & 27 & 30 & 19 & 76 & 50.60 \\
\hline Staples & 12 & 19 & 11 & 42 & 27.33 \\
\hline Tota1 & 50 & 50 & 50 & 150 & 100 \\
\hline
\end{tabular}

The percentages do not add up to 100 due to multiple or no response 


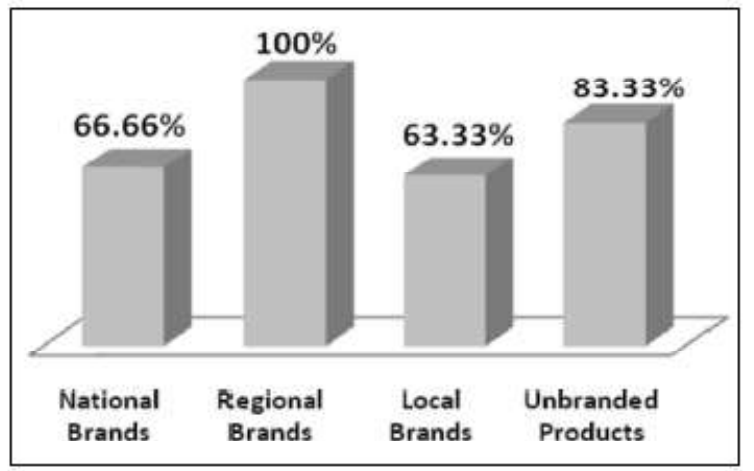

Fig 1 Kind of packaged snack products stocked by rural retailers

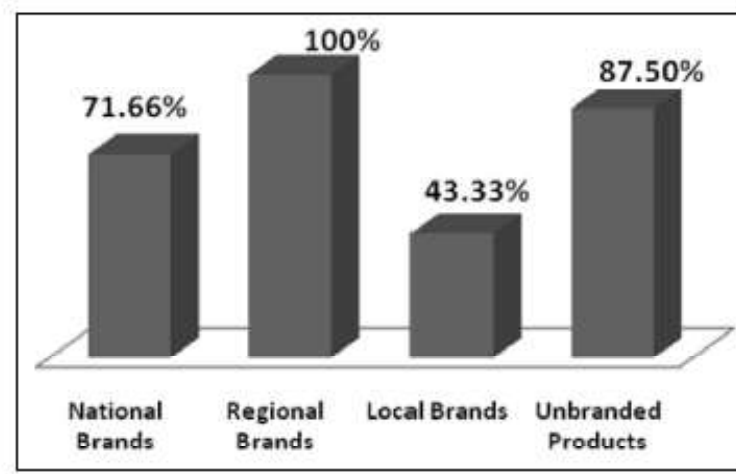

Fig 2 Kind of packaged snack products stocked by rural retailers

Table 3 SKU's kept by retailers

\begin{tabular}{lcccccccc}
\hline \multicolumn{1}{c}{ Company } & Lays & Everest & Balaji & ITC & Haldiram & Local brands & $\begin{array}{c}\text { Unbranded } \\
\text { products }\end{array}$ & Total \\
\hline Total No. of SKU's & 47 & 32 & 25 & 11 & 13 & - & - & \\
offered by company & 00 & $49(41)$ & 00 & $54(56)$ & $61(69)$ & $24(17)$ & $11(10)$ & 179 \\
Less than 5 SKU's & $00(30)$ & $62(51)$ & $72(48)$ & $30(31)$ & $18(20)$ & $\mathbf{1 1 5 ( 8 3 )}$ & $101(90)$ & 463 \\
6-10 SKU's & $64(51)$ & $10(8)$ & $60(40)$ & $12(13)$ & $09(10)$ & 00 & 00 & 158 \\
11-15 SKU's & $29(23)$ & 00 & $18(12)$ & 00 & 00 & 00 & 00 & 47 \\
More than 15 SKU's & 125 & 121 & 150 & 96 & 88 & 139 & 112 & 150 \\
No. of retailers & & & & & & &
\end{tabular}

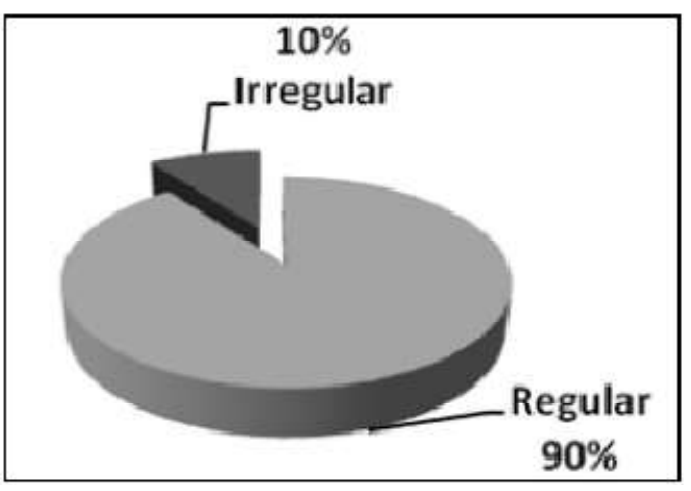

Fig 3 Regular supply of packaged products to nural retailers

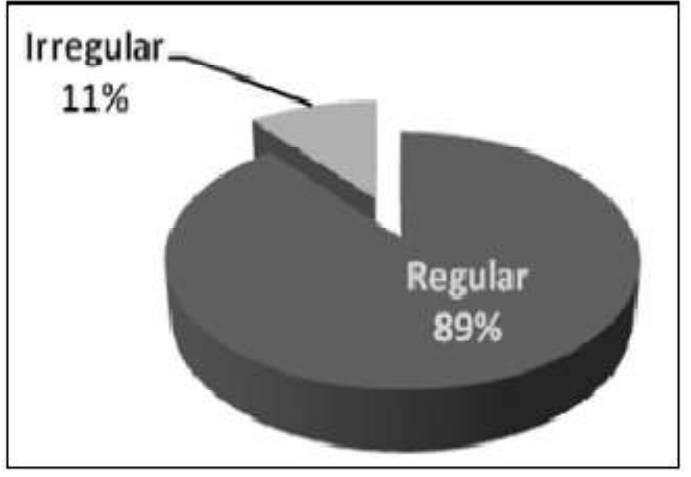

Fig 4 Regular supply of packaged products to urban retailers

Table 4 Factors influcncing purchasc of packagcd snack food products

\begin{tabular}{lccccc}
\hline Influencing factors & $\begin{array}{c}\text { No. of total rural } \\
\text { respondent }\end{array}$ & $\begin{array}{c}\text { No. of total urban } \\
\text { respondent }\end{array}$ & $\begin{array}{c}\text { No. of total } \\
\text { respondent }\end{array}$ & Percentage & Rank \\
\hline Availabilily & $30(100)$ & $110(91.60)$ & 140 & 93.33 & I \\
Taste & $23(76.66)$ & $104(86.66)$ & 127 & 84.66 & II \\
Quaullity & $19(63.33)$ & $94(78.33)$ & 113 & 75.33 & III \\
Qualily & $20(66.60)$ & $96(80.00)$ & 116 & 73.33 & IV \\
Fiesluetess & $22(73.33)$ & $48(40.00)$ & 70 & 46.33 & V \\
Piice & $18(60.00)$ & $33(27.5)$ & 51 & 34.00 & VI \\
& 30 & 120 & 150 & 100 & \\
\hline
\end{tabular}

The percenlages do not atdd up lo 100 due io mul liple vi no responise 
Table 5 Purpose behind purchase of packaged snack food

\begin{tabular}{lcc}
\multicolumn{1}{c}{ products } \\
$\begin{array}{c}\text { Prorpose behind } \\
\text { purchasing }\end{array}$ & $\begin{array}{c}\text { No. of total } \\
\text { respondent }\end{array}$ & Percentage \\
\hline Instaml gratilicaliunt & 132 & $\$ 8.00$ \\
For children & 107 & 71.33 \\
Festivals & 101 & 67.33 \\
Parties & 66 & 44.00 \\
Picnic & 81 & 54.00 \\
For grests & 54 & 36.00 \\
For school breakfast & 121 & $\$ 0.66$ \\
$\quad$ Total & 150 & 100 \\
\hline
\end{tabular}

Table 6 Ranking of various packaged snack food brands

\begin{tabular}{lcccccc}
\hline \multicolumn{1}{c}{ Parameters } & Balaji & Lays & Everest & ITC & Haldiram \\
\hline Brand name & 4.02 & 4.36 & 2.64 & 2.22 & 1.74 \\
Range of products & 4.13 & 4.42 & 3.18 & 1.63 & 1.62 \\
Margin & 4.92 & 2.46 & 2.68 & 2.48 & 2.44 \\
Quantity & 4.61 & 1.91 & 3.96 & 2.66 & 1.85 \\
Quality & 3.78 & 4.22 & 2.75 & 1.53 & 2.70 \\
Availability & 4.48 & 4.02 & 2.70 & 2.07 & 1.58 \\
Distribution network & 4.04 & 3.78 & 3.25 & 2.05 & 1.86 \\
Promotional & 1.20 & 4.72 & 3.06 & 3.02 & 2.98 \\
effectiveness & 4.69 & 3.34 & 3.30 & 2.03 & 1.63 \\
Demand & 4.30 & 1.50 & 4.01 & 3.48 & 1.70 \\
Price & 40.17 & 34.73 & 31.53 & 23.17 & 20.10 \\
\hline \multicolumn{1}{l}{ Total score } & & & & & & \\
\hline
\end{tabular}

1-Excellent, 2-good, 3-moderate, 4-poor, 5-very poor

Max rating: 10 (Market parameters) $\times 5$ (Max scale 5$)=50($ Max $)$

Table 7 Share of packaged snack food products in total food products sold by retailers

\begin{tabular}{ccccc}
\hline $\begin{array}{c}\text { Share of } \\
\text { packaged }\end{array}$ & $\begin{array}{c}\text { No. of total } \\
\text { nural }\end{array}$ & $\begin{array}{c}\text { No. of total } \\
\text { urban }\end{array}$ & $\begin{array}{c}\text { No. of } \\
\text { total }\end{array}$ & $\%$ \\
snack products & respondent & respondent respondent & \\
\hline $10-20 \%$ & $03(\mathbf{1 0 . 0 0 )})$ & $61(50.83)$ & 64 & 42.66 \\
$21-40 \%$ & $05(\mathbf{1 6 . 6 6 )}$ & $36(30.00)$ & 41 & 27.33 \\
$41-60 \%$ & $06(20.00)$ & $23(19.16)$ & 29 & 19.33 \\
$61-80 \%$ & $09(30.00)$ & $00(00.00)$ & 09 & 6.00 \\
Above $81 \%$ & $07(23.33)$ & $00(00.00)$ & 07 & 4.66 \\
Total & $30(100)$ & $120(100)$ & 150 & 100 \\
\hline
\end{tabular}

Table 8 Effect of visibility on the sales of packaged snack food products

\begin{tabular}{|c|c|c|}
\hline Effect of visibility & No. of total respondent & Percentage \\
\hline Yes & 102 & 68 \\
\hline No & 48 & 32 \\
\hline Total & 150 & 100 \\
\hline
\end{tabular}


Table 9 Satisfaction level towards incentives

\begin{tabular}{|c|c|c|}
\hline $\begin{array}{l}\text { Satisfaction level } \\
\text { towards incentives }\end{array}$ & $\begin{array}{l}\text { No. of total } \\
\text { respondent }\end{array}$ & Percentage \\
\hline $\begin{array}{l}\text { Yes } \\
\text { No }\end{array}$ & $\begin{array}{l}108 \\
42\end{array}$ & $\begin{array}{l}72 \\
28\end{array}$ \\
\hline Total & 150 & 100 \\
\hline
\end{tabular}

Table 10 Delivery of all price points according to requirement

\begin{tabular}{cccccc}
\hline $\begin{array}{c}\text { Supply as per } \\
\text { requirement }\end{array}$ & $\begin{array}{c}\text { No. of respondent } \\
\text { in Nanded }\end{array}$ & $\begin{array}{c}\text { No. of respondent } \\
\text { in Beed }\end{array}$ & $\begin{array}{c}\text { No. of respondent } \\
\text { in Hingoli }\end{array}$ & $\begin{array}{c}\text { Total no. of } \\
\text { respondent }\end{array}$ & Percentage \\
\hline Yes & 47 & 40 & 42 & 129 & $86.00 \%$ \\
No & 03 & 10 & 08 & 21 & $14.00 \%$ \\
Total & 50 & 50 & 50 & 150 & $100 \%$ \\
\hline
\end{tabular}

Table 11 Deliveries of all range of products

\begin{tabular}{|c|c|c|}
\hline $\begin{array}{l}\text { All range of products } \\
\text { delivered by sales persons }\end{array}$ & $\begin{array}{l}\text { No. of total } \\
\text { respondents }\end{array}$ & Percentage \\
\hline Yes & 134 & 89.33 \\
\hline No & 16 & 10.66 \\
\hline Total & 150 & 100 \\
\hline
\end{tabular}

Table 12 Information about new product ranges

\begin{tabular}{|c|c|c|}
\hline $\begin{array}{l}\text { Salesman tell about } \\
\text { new range }\end{array}$ & $\begin{array}{l}\text { Total no of } \\
\text { respondents }\end{array}$ & Percentage \\
\hline Yes & 136 & 90.66 \\
\hline No & 14 & 9.33 \\
\hline Total & 150 & 100 \\
\hline
\end{tabular}

Table 13 Satisfaction level of retailers with service level

\begin{tabular}{cccccc}
\hline Satisfied or not & $\begin{array}{c}\text { No. of respondent in } \\
\text { Nanded }\end{array}$ & $\begin{array}{c}\text { No. of respondent } \\
\text { in Deed }\end{array}$ & $\begin{array}{c}\text { No. of respondent } \\
\text { in IIingoli }\end{array}$ & $\begin{array}{c}\text { Total no. of } \\
\text { respondent }\end{array}$ & Percentage \\
\hline Yes & 41 & 40 & 38 & 119 & 79.33 \\
No & 09 & 10 & 12 & 31 & 20.66 \\
Total & 50 & 50 & 50 & 150 & 100 \\
\hline
\end{tabular}

Packaging material of packaged snack products was very hard. There was problem of pilferage in packaged strips when customer's children pick up one package from strip at retailers point. Because of tough competition in snack segment price is very sensitive issue for packaged snack food products. Various brands offers various products at affordable price points like in wafers segment three price point Rs. 5, Rs 10 and Rs. 20; in salty segment Rs. 3, Rs. 5,
Rs. 8, Rs. 10, Rs. 15 and Rs. 18; while in crunchy salty snack products mainly two price points Rs. 5 and Rs. 10 were offered by various brands. According to majority of retailers $(77 \%)$ Rs. 5 price point is most preferable. Distribution network of packaged snack food products is very effective. Products are regularly available even in far flung rural areas. All retailers stocked regional brands like Balaji, Samrat, Real followed by 70.66 percent retailer stocked national brands. 
$86.66 \%$ retailers stocked unbranded products. According to retailers, promotional activities affects sales of Packaged snack food products since thesetypes of products are purchased by children. National brands like ITC, Lays promote their products through TV advertisement and with Brand ambassador. These type of promotional activities helps to create awareness towards new products as well as for existing products and boosts sells of products. Not much promotional activities are undertaken by regional brands like Balaji, Samrat, and Everest. Majority (93.33\%) retailers told that availability at retail outlet is the major factor influencing purchase of packaged snack food products followed by taste, quantity, quality and freshness of the products. According to retailers wafers and crunchy salty snacks both the products are purchased most by consumers followed by wafers. Majority (81\%) retailers told that everybody purchase and consume packaged snack food products since they are good in taste and provide instant gratification. Instant gratification is the main purpose behind purchasing of packaged snack food products as per majority $(88 \%)$ retailers followed by school breakfast, festival, picnic, parties and for guests.

Packaged snack food product brands should provide replacement as if the products sold out after its expiry date may cause food poisoning or any other health problems. Packaged snack food product Brands should provide POP materials because products like wafers and crunchy salty products require extra care at shelf place, proper arrangement and visibility at shelf helps to increase sales of such snack products. Packaged snack food product brands should provide at least one week credit to retailers. Some special schemes for retailers as well as for consumer should be launched by packaged snack food product brands over a period of time (Brody 2000). More new products and new product segments like sweet Faralichevdo, Faradichevdo without red chilli powder, and wafers without salt should be introduced. Packaging should be improved as there is problem of pilferage in packaged strips since no replacement is there; it is a loss for retailer.

\section{CONCLUSION}

Increased consumer awareness and higher disposable income have been the engines driving the growth of the Indian packaged food industry. Growth of modern trade and convenience needs have further helped the growth of packaged foods. Rising disposable income has boosted individual disposable 
income levels. This has helped fuel the demand for packaged foods mainly in the urban centers. The distribution network for packaged snack food products brands is effective in urban as well as rural areas of Maharashtra but it needs to be made more effective by adopting proactive approach in product innovation, packaging, improving availability and visibility and improving the service level at distribution points. Availability, taste and freshness are the major factors affecting purchasing decision. Packaged snack food manufacturers should try to satisfy its retailers by providing POP material and different schemes over a period of time.

\section{REFERENCES}

[1] Arcan, C., Bruening, M. and Story, M. 2013. Television (TV) and TV advertisement influences on Children's eating behaviour. Retrieved on 13 August 2018, 2.50 pm from http:/www.childencyclopedia.com/childnutrition/accordingexperts/television-tv-and-tvadvertisement-influences-childrenseating,

[2] Boyland, EJ. Whalen, R. 2015. Food advertising to children and its effects on diet: review of recent prevalence and impact data. Pediatric diabetes, 331-337. doi: 10.1111/pedi.12278

[3] Brain Tracy International . (n.d.). 7 steps to develop a new habit. Retrieved on 13 August 2018, 2.08 pm from https://www.briantracy.com/blog/p ersonal-success/seven- steps-todeveloping-a-new-habit/,

[4] DE Klerk, 2008. Children's preference of fast food. Dissertation for masters in business, University of Johannesberg.

[5] Donahoe, A. 2005. America's royality: Burger king \& Dairy queen. Retrieved on 18 August 2018, $\quad 12.45$ am from http://www.lclark.edu/ soan221/96 /foodtrend.html

[6] Halford, C.G., Gillespie, J., Brown, V., Pontin, E.E., \& Dovey M. T. 2004. Effect of television advertisements for food on food consumption in children. Appetite, 42 (2004). 221- 225.

[7] Lally, P., Jaarsveld, V, C. H. M., Potts, H. W. W. and Wardle, J. 2010. How are habits formed: Modelling habit formation in the real world. European Journal of Social Psychology, 40, 998-1009

[8] Loya, S., Hussain, J. and Ismail, S. 2016. Impact of food advertisement on childhood obesity. International Journal of Innovative Research \& 
Development, 5(1), 378-385.

[9] Mishra, G. and Singh, S. 2012. Due to television commercial, change in eating habits and its direct impact on obesity of teenagers of Jammu. The public administration and social policies review, 1(8), 125136.

[10] Murty, N.T., Chowdary, R. and Rao, S. R. 2013. Impact of advertising on children with special reference to eating habits. Abhinav Journal of Research in Management \& Technology, 2, 3945.

[11] Policy brief: Evidence of effects of food advertising on children. 2016. Obesity policy coalition.

[12] Research and market report. 2015. Indian fast food market report 2015-2020: Market is expected to grow at a CAGR of $18 \%$.

"Retrieved from"https://www.prnewswire.co $\mathrm{m} /$ news-releases/india-fast-foodmarket-report-2015---2020market-is-expected-to-grow-at-acagr-of-18- 505221141.html,

[13] Shabeer, V.P. 2015. Influence of television advertisement in the food habits among the children in Kerala. International Journal of Current Research, 7(8), 1977919781.

[14] WHO Report. Marketing of food and non alcoholic beverages to children. 2006. Retrieved on 15 August 2018, 1. 11 am from http://www.who.int/ dietphysicalactivity/ publications /Oslo\% 20meeting\% 20layout\% 2027\% 20 NOVEMBER.pdf, 